This is a post-peer-review, pre-copyedit version of an article published in Biomass Conversion and Biorefinery. The final authenticated version is available online at: https://doi.org/10.1007/s13399-020-00759-1

\title{
IMPACT OF SOFT-HYDROTHERMAL PRE-TREATMENTS ON THE OLIVE MILL SOLID WASTE CHARACTERISTICS AND ITS SUBSEQUENT ANAEROBIC DIGESTION
}

\author{
M.J. Fernández-Rodríguez ${ }^{1,2}$; D. De la Lama-Calvente ${ }^{1}$; A. Jiménez-Rodríguez ${ }^{2}$; R. Pino-Mejías ${ }^{3}$; \\ R. Borja ${ }^{1}$; B. Rincón ${ }^{1}$. \\ ${ }^{I}$ Instituto de la Grasa (CSIC), Campus Universidad Pablo de Olavide. Edificio 46. Ctra. de Utrera Km. 1, \\ 41013 Sevilla, Spain. \\ ${ }^{2}$ Departamento de Sistemas Físicos y Naturales, Universidad Pablo de Olavide. Ctra.de Utrera, km 1, \\ 41013 Sevilla, Spain. \\ ${ }^{3}$ Department of Statistics and Operational Research, University of Seville, Calle Tarfia s/n, Sevilla, \\ 41012, Spain \\ E-mail of the corresponding author*: brlloren@cica.es \\ Dr. M. J. Fernández-Rodríguez: https://orcid.org/0000-0001-6130-4647 \\ Dr. A. Jiménez-Rodriguez: https://orcid.org/0000-0001-7495-4358 \\ Dr. R. Pino-Mejías: https://orcid.org/0000-0002-2743-877X \\ Dr. R. Borja: https://orcid.org/0000-0002-3699-7223 \\ Dr. B. Rincón: https://orcid.org/0000-0002-2652-9231
}

\section{DECLARATIONS}

Funding: This study was funded by:

-Project of Excellence RNM-1970 funded by the regional government of Andalucía, Junta de Andalucía, Consejería de Economía, Innovación, Ciencia y Empleo, Andalucía, Spain.

-Ramón y Cajal Program (RYC-2011-08783 contract) funded by the Spanish Ministry of Economy and Competitiveness for providing financial support to Dr. Rincón.

Conflicts of interest/Competing interests: The authors declare that they have no conflict of interest. Code availability: Sigma-Plot (version 11), statistical programming language R. 


\title{
ACKNOWLEDGMENTS
}

The authors wish to express their gratitude to the regional government of Andalucía, Junta de Andalucía, Consejería de Economía y Conocimiento (Project of Excellence RNM-1970) for providing financial support. Dr. Rincón wishes to thank the "Ramón y Cajal" Program (RYC-2011-08783 contract) from the Spanish Ministry of Economy and Competitiveness for providing financial support. The authors wish to express their gratitude to Dr. Pere Mutjé and Dr. Quim Tarrés from the LEPAMAP Group, Department of Chemical Engineering, University of Girona, Girona (Spain) for the fiber analysis and data interpretation. The authors also wish to express their gratitude to Dr. Fátima Rubio, Dr. Ana Jiménez, Dr. Guillermo Rodríguez and Dr. Joaquín Velasco from the Instituto de la Grasa (CSIC), Sevilla (Spain) for their help with part of the analysis.

\begin{abstract}
The aim of this study was to investigate the effect of a soft-hydrothermal pre-treatment (SHP) on olive mill solid waste (OMSW) and its subsequent anaerobic digestion (AD). OMSW was pre-treated in an autoclave at temperatures of $121^{\circ} \mathrm{C}$ and $133^{\circ} \mathrm{C}$ and excess pressures of 1.1 and 2.1 bars, respectively at heating times of 15, 20 and 30 minutes. The digestibility of pre-treated and untreated OMSW was determined in terms of methane potential through using biochemical methane potentials tests (BMP). An important solubilisation of high valuable compounds such us hydroxytyrosol, and 3,4dihydroxyphenylglycol was observed after pre-treatments. SHP showed a significant reduction on fiber length and width $(\mathrm{p}<0.05)$. A higher polysaccharides solubilisation was observed in treatment at $121^{\circ} \mathrm{C}$ comparing with that observed at $133{ }^{\circ} \mathrm{C}$. SHP carried out at $121{ }^{\circ} \mathrm{C}, 1.1$ bar $(30 \mathrm{~min})$ (pre-treatment A1), allowed obtaining the highest methane yield $\left(380 \pm 5 \mathrm{~mL} \mathrm{CH}_{4} / \mathrm{g} \mathrm{VS}\right)$, which was $12.3 \%$ higher than that obtained for untreated OMSW. Pearson correlation (PEC) and Principal Component Analysis (PCA) were carried out. PEC showed a positive correlation with phenol vanillic acid and PCA grouped pre-treatment A1 with polysaccharides solubilization. The influence of the SHP conditions on the AD of OMSW was assessed through the monitoring of process performance and calculation of kinetic parameters by using the Transference Function model.
\end{abstract}

Keywords: Autoclaving; Soluble chemical oxygen demand; Polysaccharides; Phenol inhibition; Kinetic study. 


\section{INTRODUCTION}

$98 \%$ of the olive cultivation areas are located in Mediterranean zones which produce $97 \%$ of the olive oil in the world. In the 2016-2017 season, the worldwide olive oil production was $2,586,500$ tons, $44 \%$ of this production came from Spain [1,2].

The two-phase olive mill solid waste (OMSW) is a thick sludge that is a mixture of stone and pulp of the olive fruit, as well as olive mill wastewater. The OMSW is mainly composed of water (60-70\%), lignin $(13-15 \%)$, cellulose and hemicellulose (18-20\%), olive oil retained in the pulp $(2.5-3 \%)$ and mineral solids $(2.5 \%)$, which result in an elevated polluting load with a chemical oxygen demand (COD) in the range of $300-350 \mathrm{~g} \mathrm{O}_{2} / \mathrm{kg} \mathrm{[3].}$

The anaerobic digestion (AD) of lignocellulosic wastes has been proven to be a more convenient and feasible option compared to other treatments such as physical, physicochemical or biological aerobic treatments due to: a) a high degree of purification can be achieved with high-organic-load feeds; b) low nutrient requirements; c) small quantities of excess sludge are produced; d) a combustible biogas enables the process to generate energy [4]. Additionally, AD consumes less energy than other thermochemical recovery methods such as pyrolysis. Also, for wet waste (as in the case of OMSW) it does not require a drying phase. The AD process occurs in a sequence of four biological steps, c.a. hydrolysis, acidogenesis, acetogenesis and methanogenesis. In case of complex substrates, the hydrolysis is the rate-limiting step, where hydrolytical bacteria release extracellular enzymes which break down organic particulate matter and allow it to solubilize [5].

Thus, AD has been proposed for the treatment of OMSW and the results show, at mesophilic temperature, a COD removal efficiency in the range of $96.8 \%-82.9 \%$ [6]. AD is difficult to apply for lignocellulosic residues such as OMSW, the presence of lignin greatly limits hydrolytic step of $\mathrm{AD}$, as well as the crystallinity of cellulose, which limits the surface availability by reducing the biodegradability [7]. To overcome these restrictions and improve its biodigestibility, a pretreatment it is generally required to break the complex lignocellulosic structure. Various pretreatment methods previously assayed for OMSW were Fenton [7], ultrasonic and thermal [8-9].

Pretreatment is the most effective way to reduce the recalcitrant compounds, and is essential for commercial scale biomethane production. Thermal, thermo-chemical and enzymatic pre-treatments, twostage $\mathrm{AD}$, composting, ensiling and mechanical treatments have been studied in order to enhance the 
methane production of lignocellulosic biomass by reducing the hydrolytic step [10-11]. Other alternative method for conventional heating could be Microwave pretreatment which induces an enhancement of the kinetic constant value of the subsequent $\mathrm{AD}$ process because the lignocellulosic biomass is affected and the enzymes access easier to their targets [12]. Ultrasonic physical method was used recently by Pansripong et al. [13] as an AD pretreatment, and concluded that ultrasonic provided a higher methane yield compared to the untreated one [13]. Carrere et al. [10] concluded that the best treatment for lignocellulosic biomass first requires delignification, followed by hemicellulose and cellulose alkali or biological hydrolysis, although there is no mention of hydrothermal pre-treatments.

The typical hydrothermal treatments by Liquid Hot Water (LHW) are carried out at relatively high temperature $\left(160-240{ }^{\circ} \mathrm{C}\right)$ and pressure $(1-3.5 \mathrm{MPa})$, during a few minutes to several hours and diluted in water [14]. This pre-treatment enhanced the dissociation of water molecules which act as an acidic catalyst. LHW eliminates problems of corrosion, compared to chemical treatments, and reduces operational costs, compared to enzymatic treatments [15-16]. LHW pre-treatment (at $160{ }^{\circ} \mathrm{C}, 20 \mathrm{~min}$, under variable pressure) enhanced the methane production yield by $76 \%$ when using sugar beet pulp as substrate [16]. Dos Santos Rocha et al. [17] showed that LHW $\left(195{ }^{\circ} \mathrm{C} / 15 \mathrm{~min}\right)$ pre-treatment of sugarcane straw reached $85 \%$ and $21 \%$ of hemicellulose and cellulose removal, respectively. Abu Tayeh et al. [18] showed that LHW pre-treatment combined with C1-C2 organic acids improved enzymatic saccharification of OMSW at mild temperatures and pressure $\left(120,140\right.$ and $170{ }^{\circ} \mathrm{C} ; 10-13$ atm). Jia et al. [19] showed that short-term hydrothermal pre-treatment (STH) (50\%dilution in water and treatment at 90 ${ }^{\circ} \mathrm{C}, 30 \mathrm{~min}$ ) of food waste before two-stage $\mathrm{AD}$ enhances the production of biogas when comparing with the process without pre-treatment or with one-stage AD. In this case, the maximum biogas production rate $\left(R_{\max }\right)$ reached was improved by $59 \%$ in the hydrolytic step and by $5 \%$ in the methanogenic step.

Another type of hydrothermal pre-treatment is autoclaving. This method consists of high pressure sterilization of waste by steam, which cooks the waste and destroys most of the bacteria in it. Temperature and time usually range between $120^{\circ} \mathrm{C}$ and $160{ }^{\circ} \mathrm{C}$ within $1 \mathrm{~h}[20]$. Most of the published results show an increase in methane production at temperatures around $160^{\circ} \mathrm{C}$ and excess pressures of 5-6 bars [21, 22]. Bougrier et al. [23] reported that the use of higher temperatures $\left(>180{ }^{\circ} \mathrm{C}\right)$ decreased the biodegradability of the wastes. Then, the lower initial biodegradability, the higher the impact of thermal treatment by the presence of non-biodegradable compounds into the soluble phase. As a special case, the 
soft-hydrothermal pre-treatment (SHP) in this study consisted of the autoclaving of OMSW at low temperatures $\left(120^{\circ} \mathrm{C}-130^{\circ} \mathrm{C}\right)$ and pressures $(1-2$ bar $)$.

The most significant drawback of high temperature pre-treatments is the high energy requirement that reduces the overall profitability of the process due to the pretreatment high cost [24]. Also, hightemperature thermal pre-treatments have others disadvantage like releasing soluble-sugar-derived byproducts such as furfural, 5-hydroxymethyl furfural (5-HMF), or lignin-derived by-products such as vanillin, syringaldehyde and other phenolic compounds [25]. Their concentrations and nature depend mainly on the biomass origin, but also on the kind of pre-treatment, contact time, $\mathrm{pH}$, pressure, temperature, concentration and solid loading [26]. These compounds have shown an inhibitory effect in several processes [27]. Monlau et al. [28] reviewed the literature data on the impact of pre-treatment byproducts on $\mathrm{AD}$ processes when using mixed cultures as inoculum and concluded that no minimal inhibitory concentration of each by-product has been successfully found nor the synergistic effect between different by-products.

Soft-thermal pre-treatments (SHP) and their effect on subsequent AD processes have been less studied and few research works dealing to this subject were reported in the literature [24,29]. Even more limited are the studies dealing to the influence of soft hydrothermal pretreatments on the chemical characteristics of lignocellulosic biomass [29]. Therefore, the aim of the present study was to assess the effect of a SHP on the chemical composition of OMSW using temperatures of $121^{\circ} \mathrm{C}$ and $133^{\circ} \mathrm{C}$ and pressures of 1.1 and 2.1 bar, respectively, at heating times of 30, 20 and 15 min for each treatment. Soluble COD (sCOD), phenol composition, sugar and fiber length were determined after pre-treatment. The digestibility of pretreated OMSW compared to untreated OMSW was determined in terms of methane potential through biochemical methane potential (BMP) tests. Kinetic modelling of the BMP assays was also performed. The principal component analysis (PCA) and Pearson correlation (PEC) were applied in order to comprehend how affected the different SHPs to methane production.

\section{MATERIALS AND METHODS}

\subsection{OMSW}

The two-phase OMSW was collected from the Experimental Olive Oil Mill Factory (Instituto de la Grasa (CSIC), Seville,Spain). In order to remove olive stone pieces, the OMSW was sifted through a $2 \mathrm{~mm}$ 
mesh. The main characteristics of the OMSW used in the experiment were: $\mathrm{pH}: 4.8 \pm 0.2$, total solids (TS): $258.4 \pm 0.9 \mathrm{~g} / \mathrm{kg}$, volatile solids (VS): $225.7 \pm 0.3 \mathrm{~g} / \mathrm{kg}$, total chemical oxygen demand (tCOD): 324 $\pm 13 \mathrm{~g} \mathrm{O}_{2} / \mathrm{kg}$, soluble chemical oxygen demand (sCOD): $3109 \pm 33 \mathrm{mg} \mathrm{O} / \mathrm{kg}$, moisture content: $74.2 \pm$ $0.2 \%$.

\subsection{SHP}

Six different SHPs were carried out on OMSW in an autoclave (Raypa series AH-RFG). The pretreatment $\mathrm{A}$ was carried out at $121^{\circ} \mathrm{C}$ and pressure of 1.1 bar for 30,20 and 15 min (A1, A2 and $\mathrm{A} 3$, respectively). The pre-treatment $\mathrm{B}$ was performed at $133^{\circ} \mathrm{C}$ and 2.1 bar for 30,20 and $15 \min (\mathrm{B} 1, \mathrm{~B} 2$ and B3, respectively). These temperatures were chosen based on previous results on thermal pretreatments of other lignocellulosic biomasses [20,21]. These results have shown that the main factors influencing the autoclaving pre-treatment are temperature, pressure and time. In this sense, these studies revealed the effectiveness of this pre-treatment in BMP assays of lignocellulosic biomass when it is pretreated for 15-30 minutes at 2 bars and $134{ }^{\circ} \mathrm{C}$ [20]. $500 \mathrm{~g}$ of OMSW were introduced into a 1L autoclavable bottle for each pre-treatment and then autoclaved under the different selected conditions. The samples were stored at $4{ }^{\circ} \mathrm{C}$ (less than 24 h until use).

\subsection{Analytical methods and equipment}

The pre-treatments were carried out in an automatic autoclave Raypa with counter pressure (series AHRFG).

The untreated and pre-treated OMSWs as well as the anaerobic digestates after the AD were analyzed. All substrates were characterized by the measurement of total COD (tCOD) [30]. Volatile solids (VS) were determined according to the standard methods 2540E [31]. Total alkalinity was analyzed by $\mathrm{pH}$ titration (pH-meter model Crison 2.0 Basic) [31]. Fiber viscosity was determined according to Norm UNE-ENISO 5351:2004 [32]. Total oil content was determined by the Soxhtlet extraction method using hexane as solvent [33]. The oil fraction was analyzed by high pressure size exclusion chromatography to determine the content of triglycerides, diglycerides and fatty acids according to the IUPAC Standard Method 2.508 [34].

Soluble parameters were determined after sample centrifugation (7500 rpm, $8 \mathrm{~min})$ and two filtrations (filter paper and glass fiber filter). sCOD was determined by a closed digestion and the standard method 
5220D [31]. Soluble total phenolic content was determined by the Folin-Ciocalteu method [35], while carbon and nitrogen were determined through an Elemental Analyzer LECO CHNS-932 (LECO Corporation, St. Joseph, MI, EEUU). In order to obtain a distribution of the untreated and pre-treated OMSW fiber lengths and diameters, the matrix was dissolved using a Soxhlet apparatus and decalin as solvent. Untreated and pre-treated OMSW were as previously filtered using a cellulose filter and set into the Soxhelt equipment $(48 \mathrm{~h})$. The obtained fibers were rinsed with acetone and distilled water, the fibers were dried in an oven at $105^{\circ} \mathrm{C}(24 \mathrm{~h})$.

The length and diameter distributions of the fiber were characterized using a morphological fiber analyser (Techpap SAS, France).

\subsection{Analysis of individual compounds}

Individual phenols and acetic acid were quantified using a Hewlett-Packard 1100 liquid chromatography system using a diode array detector with Rheodyne injection valves (loop of $20 \mathrm{~mL}$ ) and quantification wavelengths of 254, 280 and $340 \mathrm{~nm}$. A C18 column (250 mm x $4.6 \mathrm{~mm}$ internal, diameter $5 \mathrm{~mm})$ was used. Milli Q water acidified (0.01\% trichloroacetic acid and acetonitrile) was used as mobile phase. The gradient applied was $95 \%$ at the beginning, $75 \%$ in $30 \mathrm{~min}, 50 \%$ in $45 \mathrm{~min}, 0 \%$ in $47 \mathrm{~min}, 75 \%$ in $95 \mathrm{~min}$ and $95 \%$ in $52 \mathrm{~min}$, being the total run time of $55 \mathrm{~min}$.

The soluble polysaccharide composition was determined by acid hydrolysis with $2 \mathrm{~N}$ trifluoroacetic acid $\left(121^{\circ} \mathrm{C}, 1 \mathrm{~h}\right)$ [36], derivatization to alditol acetates and quantification by gas chromatography. The soluble monosaccharide composition was quantified by gas chromatography [37].

A HP 6890 Plus+ gas chromatograph (Hewlett-Packard, Palo Alto, CA) fitted with a $30 \mathrm{~m}$ x $250 \mu \mathrm{m}$ x $0.20 \mathrm{~mm}$ capillary column (SP-2330, Supelco, Bellefonte, PA) was used. The carrier gas was helium (constant flow of $2.2 \mathrm{~mL} / \mathrm{min}$ and $21.5 \mathrm{psi}$ ). Injection was performed in splitless mode. The oven temperature was held at $50{ }^{\circ} \mathrm{C}$ for 2 min after injection, then programmed to $180{ }^{\circ} \mathrm{C}$ at $35^{\circ} \mathrm{C} / \mathrm{min}$, held at $180{ }^{\circ} \mathrm{C}$ for $5 \mathrm{~min}$, and then immediately increased to $220^{\circ} \mathrm{C}$ at $5^{\circ} \mathrm{C} / \mathrm{min}$, and held at $220{ }^{\circ} \mathrm{C}$ for $22 \mathrm{~min}$. Total run was $40.7 \mathrm{~min}$. The injector temperature was $250^{\circ} \mathrm{C}$, flame ionization detector (FID), $300{ }^{\circ} \mathrm{C}$. Neutral sugars, L-rhamnose, D-fucose, L-arabinose, D-xylose, D-mannose (Man), D-galactose and Dglucose were identified. myo-Inositol was used as internal standard. 
The total carbohydrates were estimated by the anthrone assay [38]. The absorbance values of the standards and samples were measured at $630 \mathrm{~nm}$ in a microplate reader (MPM 600; Bio-Rad Laboratories, Inc., Hercules, CA).

\subsection{Inoculum for $\mathrm{AD}$}

The anaerobic sludge used as inoculum in the reactors was collected from an industrial up-flow anaerobic sludge blanket reactor which treats brewery wastewater in Seville (Spain). The main characteristics of the inoculum used were: $\mathrm{pH}: 6.77$; TS: $28.7 \pm 2.7 \mathrm{~g} / \mathrm{kg}$; VS: $22.8 \pm 2.3 \mathrm{~g} / \mathrm{kg}$.

\subsection{BMP tests}

The BMP tests were carried out in a thermostatic bath at mesophilic temperature $\left(35 \pm 2^{\circ} \mathrm{C}\right)$. Each reactor had an effective volume of $250 \mathrm{~mL}$ and was continuously stirred with magnetic bars (450 rpm). The inoculum/substrate ratio was 2 (on a VS basis). For each reactor containing $210 \mathrm{~mL}$ of inoculum, the amount of substrate needed to give the required inoculum to substrate ratio was added together with trace element solution [3]. Two reactors with the inoculum and trace element solution (without substrate addition) were used as controls.

The reactors were sealed and the headspace of each flask was flushed with nitrogen at the beginning of the assay. The produced biogas was passed through a $3 \mathrm{~N} \mathrm{NaOH}$ solution to capture $\mathrm{CO}_{2}$; the remaining gas was assumed to be methane. Thus, methane production was determined by liquid displacement. All the methane volumes and yields included in the present work were expressed at standard temperature and pressure (STP) conditions $\left(0^{\circ} \mathrm{C}, 1\right.$ atm).

Seven different substrates (untreated and pre-treated OMSW at different conditions: A1, A2, A3, B1, B2 and B3) were digested in order to show the effect of pre-treatment on the AD. The AD experiments were run in batch mode for a period c.a. of 30 days until the accumulated gas production remained unchanged, i.e. on the last day production was lower than $2 \%$ of the accumulated methane produced. Each experiment was carried out in triplicate.

\subsection{Kinetic study}

The Transference Function (TF) model was applied to fit the experimental data of methane production during BMP tests (eq. 1) [39-41]: 
$B=B_{\max } *\left(1-\exp \left[-\frac{R_{\max }(t-\gamma)}{B_{\max }}\right]\right)$

Where $B\left(\mathrm{~mL} \mathrm{CH}_{4} / \mathrm{g} \mathrm{VS}_{\text {added }}\right)$ is the cumulative specific methane production, $B_{\max }\left(\mathrm{mL} \mathrm{CH}_{4} / \mathrm{g} \mathrm{VS}_{\text {added }}\right)$ is the ultimate methane production, $R_{\max }$ is the maximum methane production rate $\left(\mathrm{mL} \mathrm{CH}_{4} / \mathrm{g} \mathrm{VS}_{\text {added }} \cdot \mathrm{d}\right), t$ (d) is the digestion time and $\gamma(\mathrm{d})$ is the lag time.

Error $(\%)$, Regression coefficient $(\mathrm{R})$, determination coefficient $\left(\mathrm{R}^{2}\right)$ and standard error of estimate $\left(\sigma_{\mathrm{est}}\right)$ were calculated to evaluate the goodness-of-fit and the accuracy of the results. Error was defined as the percentage difference between the experimental and the predicted or theoretical methane yield coefficient. The kinetic parameters for each experiment and mathematical adjustment were determined numerically from the experimental data obtained by non-linear regression using the software Sigma-Plot (version 11).

\subsection{Statistical significance tests}

For this study the Analysis of variance (ANOVA) test was used in order to determine whether the different pre-treatments showed any significant variation in any of the determined parameters. A significance level (p) of 0.05 was used. PEC coefficient was computed to measure the linear association between methane and the analyzed variables. PCA was applied to the whole set of standardized variables, including methane, in order to explain the correlation structure and clarify the effect of each SHP on methane production. The PCA technique has been chosen for its reduced dimensionality ability, increasing its interpretability and therefore minimizing information loss [42]. The statistical analysis was performed with the statistical programming language $\mathrm{R}$ [43].

\section{RESULTS AND DISCUSSION}

\subsection{Effects of the different pre-treatments on chemical oxygen demand}

Figure 1 shows the total and sCOD of the substrate after each pre-treatment. No $(\mathrm{p}>0.05)$ differences were found in tCOD between treated substrates and untreated OMSW. The untreated OMSW had a tCOD of $324 \pm 13 \mathrm{~g} \mathrm{O}_{2} / \mathrm{kg}$ and there were slight differences after each treatment, ranging from $323 \pm 9 \mathrm{~g} \mathrm{O}_{2} / \mathrm{kg}$ to $344 \pm 9 \mathrm{~g} \mathrm{O}_{2} / \mathrm{kg}$. However, taking the sCOD into consideration, it can be stated that $\mathrm{SHP}$ at $121{ }^{\circ} \mathrm{C}$ and $133{ }^{\circ} \mathrm{C}$ had a positive effect on organic soluble material release as $(\mathrm{p}<0.05)$ differences were found. According to these results, experiment A3 showed the lowest release of organic matter (sCOD: $167.7 \pm$ $1.1 \mathrm{~g} \mathrm{O}_{2} / \mathrm{L}$ ), which was $28 \%$ higher than that observed in the untreated OMSW; experiments $\mathrm{A} 1, \mathrm{~A} 2$, 
presented a similar sCOD with no significant differences $(\mathrm{p}>0.05)(168.9 \pm 1.1$ and $169.0 \pm 2.1 \mathrm{~g} \mathrm{O} / \mathrm{L}$, respectively), which were $29 \%$ higher than that observed in the untreated OMSW. Similarly, Şenol et al. [44] determined an increase in organic matter solubilisation after corn silage thermal pretreatment at $120^{\circ} \mathrm{C}$ during 10, 20 and 30 minutes. The solubilisation was of 15,21 and $43 \%$, respectively.

sCOD in B2 pre-treatment was $192.6 \pm 2.4 \mathrm{~g} \mathrm{O}_{2} / \mathrm{L}$ and $193.2 \pm 1.5 \mathrm{~g} \mathrm{O}_{2} / \mathrm{L}$ for B3 pre-treatment, which is slightly higher than that was observed in experiment A3 and were $47 \%$ higher than that observed in the untreated OMSW. However, experiment B1, the more extreme pre-treatment, showed a significant increase in sCOD $(\mathrm{p}<0.05)\left(208.3 \pm 2.6 \mathrm{~g} \mathrm{O}_{2} / \mathrm{L}\right)$, which was $59 \%$ higher than that observed in the untreated OMSW $\left(131.1 \pm 3.3 \mathrm{~g} \mathrm{O}_{2} / \mathrm{L}\right)$. Thermal pretreatment of OMSW at 120 and $180{ }^{\circ} \mathrm{C}$ without pressure during $180 \mathrm{~min}$ [3] resulted in lower percentages of COD solubilisation (42\%) than that obtained during B pretreatments (59\% for B1 and 47\% for B2 and B3, respectively).

These results are consistent with TOC, TC results (data not shown) and previous studies in which pretreatments help to break the lignocellulosic fibers and, therefore, to solubilize organic matter [45].

\subsection{Effects of the different pre-treatments on lipids}

The experimental results showed that pre-treatments had no effect on lipids. The total lipid concentration for untreated OMSW was $13 \%$, and similar results with no differences $(\mathrm{p}>0.05)$ appeared in every substrate after pre-treatment (Table 1). The lipid fraction content of diglycerides, triglycerides and free fatty acids were also constant in all cases, since the hydrolysis of olive oil occurs at temperatures higher than $180{ }^{\circ} \mathrm{C}$ and atmospheric pressure [46].

\subsection{Effect of the different pre-treatments on fiber and soluble sugars}

OMSW is a lignocellulosic substrate mainly composed of three types of polymers: cellulose, hemicellulose and lignin. When the OMSW was subjected to different pre-treatments, these fibers were affected by being shortened approximately by half, both in length and width, which favoured the AD due to the fact that fibers were converted to microfibers that had a greater accessibility to bacteria than in the OMSW without pre-treatment. No pre-treatment showed significant differences $(\mathrm{p}>0.05)$ between fiber length or diameter, but there were $(\mathrm{p}<0.05)$ differences between the untreated OMSW and the different pre-treatments. It could also be observed that these treatments increased the ratio of macrofibrils, which would indicate a greater surface fibrillation (Table 2). 
A certain degree of polymerization was observed, which increased with pre-treatment temperature and time exposure (Table 2). Sannigrahi et al. [47] found similar results when observing that biomass from monomeric sugar could further react and form pseudo-lignin. This result was found after an acid treatment. Several authors stated that in the hydrothermal pre-treatment (temperature and pressure) the moisture content of the biomass acts as an acid catalyst [15]. At high temperatures, the $\mathrm{H}^{+}$and $\mathrm{OH}^{-}$ present in biomass water content facilitate acid- or base- catalyzed reactions, which promotes the further degradation of some organic compounds [48].

The shortened fibers of the OMSW during pre-treatment did not release more monosaccharides into the soluble phase of OMSW (Table 3).

The soluble monosaccharide study (Table 3 ) revealed that there were no significant differences $(p>0.05)$ between treated and untreated OMSW for fucose, arabinose, xylose and galactose as can be seen in Table 3. The non-release of monosaccharides could be explained by the polymerization of released sugars which could bond with other sugars or phenols [47]. However, in the B1 experiment, manose and glucose were found to be present at $5.8 \%$ and $16.9 \%$ higher, respectively than in the other treated or untreated OMSW. In view of these results two factors must be considered regarding released sugars: on the one hand, a higher temperature and time must release more soluble sugars; while at the same time polymerization must increase with a raise in temperature and time. In this study only the manose and glucose from experiment B1 (higher temperature and time) showed a net increase compared to the untreated OMSW.

Nevertheless, polysaccharides (Figure 2) showed an increase after pre-treatment ( $<<0.05)$, with A1 (lower temperature and higher time) and B2 (higher temperature and intermediate time) showing the highest contents. Polysaccharides, which contain mannose, were only solubilized during the A1 pretreatment, although the instability of mannose in an analysis method could be the reason for this absence [36]. Galactose and fucose polysaccharides were solubilized in each treatment, with A1 being the treatment that more polysaccharides with galactose and fucose solubilized. The B2 treatment showed a similar solubilization of fucose polysaccharides.

Slight solubilization of rhamnose polysaccharides were shown after every treatment. Arabinose and xylose polysaccharides were solubilized in every case, but the maximum solubilization of this polysaccharide was found during the pre-treatments A1 and B2 (Figure 2). Glucose polysaccharide was solubilized in all pre-treatments except in B1. 
The presence of polysaccharides from non-glucose-monomers suggested that the fibers that were primarily affected by pre-treatments were hemicelluloses and pectin [49]. Several studies showed that the critical temperature for hemicellulose degradation is within a range of $150-300{ }^{\circ} \mathrm{C}[50]$, for lignin it is $150-700{ }^{\circ} \mathrm{C}[50]$ and that cellulose decomposed in a range of $300-400{ }^{\circ} \mathrm{C}$ [50]. The results from this study suggest that SHP could degrade fiber, except cellulose, at lower temperatures due to the use of pressure. However, these temperatures and pressures were not drastic enough to generate lignocellulosic-derivate by-products such as furans [51].

\subsection{Effect of the different pre-treatments on soluble phenols (SP)}

The concentration of the main phenols in the untreated olive mill solid waste and in the pre-treated OMSW after six different pre-treatments is illustrated in Table 4. In all cases pre-treatment an increase in phenol concentration in the soluble phase was observed compared to the untreated OMSW. Therefore, SHPs can be considered as efficient extraction procedures of phenols with high antioxidant capacity. While the untreated OMSW had a total concentration of $7.91 \pm 0.04 \mathrm{~g} / \mathrm{L}$, the A1 pre-treatment solubilized up to $22.9 \%$ more. The same trend was observed when comparing the temperatures of the pre-treatments. In addition, it was determined that the higher the exposure time, the higher the phenol solubilization. The maximum phenols solubilization seems to be attained at 30 minutes and at a temperature of $121^{\circ} \mathrm{C}(\mathrm{A} 1$ pre-treatment). At $133{ }^{\circ} \mathrm{C}$ there was a decrease in total phenol contents $(9.0 \pm 0.2,8.7 \pm 0.2$ and $8.5 \pm 0.3$ $\mathrm{g} / \mathrm{L}$ for B1, B2 and B3, respectively).

Abdessalem et al. [52] reported that the percentage of phenols in dates decreased with severity of treatment because the pre-treatment solubilized a greater portion of the cell wall material, mainly hemicelluloses that can be linked with simple phenols. The conditions used by Abdessalem et al. [52] were either 140 or $160{ }^{\circ} \mathrm{C}$ for $30 \mathrm{~min}$ and at a maximum pressure of $9 \mathrm{~kg} / \mathrm{cm}^{2}$. Temperature rather than exposure time seemed more important for phenol solubilization. It is worth mentioning that all the pretreatments had a significant effect on total phenol release but in this work, there were no significant differences among the three pre-treatments $(\mathrm{p}>0.05)$. On the other hand, in the B pre-treatments there were significant differences between the time exposure of 15 minutes $(8.56 \pm 0.08 \mathrm{~g} / \mathrm{L})$ and the other pretreatment durations $(8.90 \pm 0.25 \mathrm{~g} / \mathrm{L})(\mathrm{p}<0.05)$.

The composition of individual phenols in the soluble phase of OMSW was similar to the composition previously reported by Rubio-Senent et al. [53]. Table 4 illustrates the main phenols present in the 
soluble phase of the OMSW were 3,4-dihydroxyphenylglycol (DHPG), hydroxytyrosol (HT), tyrosol (T), hydroxytytosol-glucoside (Glu-HT), vanillin (V) and vanillic acid (Va).

The initial content of DHPG in the OMSW was $22.9 \pm 0.3 \mathrm{mg} / \mathrm{L}$. At $121^{\circ} \mathrm{C}$ the content of this phenol in the soluble phase increased, reaching values of $405.4 \pm 0.4,371.0 \pm 0.2,363.9 \pm 0.3 \mathrm{mg} / \mathrm{L}$ for pretreatments A1, A2 and A3, respectively. At this temperature, the solubilization of this phenol increased with the pre-treatment duration. An increase in the pre-treatment temperature led to lower DHPG solubilization, probably as a result of phenol degradation [54] or the absorption of simple phenols to a polymeric phenolic fraction which was enhanced by the severity of the thermal pre-treatment [55]. Therefore, the DHPG varied from $346.9 \pm 0.2 \mathrm{mg} / \mathrm{L}$ for pre-treatments B1, to $348.0 \pm 0.5$ and $348.9 \pm 0.6$ mg/L for B2 and B3, respectively. Temperature, pressure and time affected DHPG solubilization. The statistical analysis revealed that DHPG contents in the soluble phase were significantly different for each case ( $<<0.05$ ). At $121{ }^{\circ} \mathrm{C}$ (A experiment) this phenol content increased with time, while at $133{ }^{\circ} \mathrm{C}$ the phenol content decreased slightly with time.

Temperature and pressure had a great effect on Glu-HT solubilization. The content of this phenol in the soluble phase of OMSW was $126.9 \pm 0.2 \mathrm{mg} / \mathrm{L}$. During the pre-treatment at $121{ }^{\circ} \mathrm{C}(1.1$ bar $)$ the concentration of Glu-HT reached $295.9 \pm 0.2 \mathrm{mg} / \mathrm{L}$ after 30 minutes, $275.1 \pm 0.4 \mathrm{mg} / \mathrm{L}$ after 20 minutes and $250.9 \pm 0.4 \mathrm{mg} / \mathrm{L}$ after 15 minutes. A more severe pre-treatment $\left(133^{\circ} \mathrm{C}, 2.1\right.$ bar) solubilized $267.5 \pm$ $0.5 \mathrm{mg} / \mathrm{L}$ after 30 minutes, $289.9 \pm 0.2 \mathrm{mg} / \mathrm{L}$ after 20 minutes and $300.1 \pm 0.1 \mathrm{mg} / \mathrm{L}$ after 15 minutes. Like DHPG, the Glu-HT concentration in the soluble phase increased with time at $121{ }^{\circ} \mathrm{C}$; while it decreased at $131^{\circ} \mathrm{C}$, similar results were obtained by Abdessalem et al. [52].

In the case of HT, the lowest value in the soluble phase was obtained for the untreated OMSW $(40.6 \pm 0.0$ $\mathrm{mg} / \mathrm{L})$, while the highest value was observed for B3 pre-treatment $(658.9 \pm 0.8 \mathrm{mg} / \mathrm{L})$. However, when the time of exposure increased the concentration of HT in the soluble phase decreased drastically up to $522.2 \pm 0.5 \mathrm{mg} / \mathrm{L}$ after 30 minutes. When the samples were subjected to $121{ }^{\circ} \mathrm{C}$ the maximum solubilization of this phenol was produced after 20 minutes $(588.9 \pm 0.5 \mathrm{mg} / \mathrm{L})$; while after 30 minutes it was $582.3 \pm 0.6 \mathrm{mg} / \mathrm{L}$, and the minimum solubilization was produced after 15 minutes $(409.3 \pm 0.7$ $\mathrm{mg} / \mathrm{L})$.

Table 4 shows the release of $\mathrm{T}$ after each pre-treatment. The initial concentration of $\mathrm{T}$ in the soluble phase of the OMSW was $142.2 \pm 0.3 \mathrm{mg} / \mathrm{L}$. T looked like a more thermostable phenol and had its maximum 
concentration at $133{ }^{\circ} \mathrm{C}$ after 20 minutes, reaching up to $214.5 \pm 0.2 \mathrm{mg} / \mathrm{L}$. At $121{ }^{\circ} \mathrm{C}$ the maximum solubilization was achieved after 30 minutes although the concentration was lower than at $133^{\circ} \mathrm{C}$.

The initial concentration of $\mathrm{Va}$ in the soluble phase of the untreated OMSW was $9.3 \pm 0.2 \mathrm{mg} / \mathrm{L}$. At 133 ${ }^{\circ} \mathrm{C}$ the concentration decreased to $7.3 \pm 0.1 \mathrm{mg} / \mathrm{L}$ and $8.3 \pm 0.1 \mathrm{mg} / \mathrm{L}$ after 30 (B1) and 20 (B2) minutes, respectively; while after 15 minutes (B3) the concentration was higher (14.2 $\pm 0.1 \mathrm{mg} / \mathrm{L})$. Nevertheless, at $121{ }^{\circ} \mathrm{C}$ the Va concentration increased regardless of the time, reaching its maximum concentration after 20 minutes of pre-treatment exposure $(32.6 \pm 0.1 \mathrm{mg} / \mathrm{L})$. These results suggest that at $121{ }^{\circ} \mathrm{C}$ the solubility of Va was faster and greater than its degradation; while at $133{ }^{\circ} \mathrm{C}$ after 20 minutes, the degradation of Va occurred faster than its solubilization.

Although the concentration of $\mathrm{V}$ increased with both pre-treatments, during $\mathrm{A}$ pre-treatment the concentration of this phenol was higher when the time of exposure increased. The most severe pretreatment steadily increased the concentration of $\mathrm{V}$ in the soluble phase but when the time of exposure was 30 minutes, the concentration of this phenol decreased in the soluble phase.

Pourier et al. [56] studied the phenolic compounds effect on AD and on the microbiota. They concluded that when phenolic compounds were at concentrations less than $0.50 \mathrm{~g} / \mathrm{L}$, optimized AD performance was preserved regardless initial phenol concentration and $\mathrm{AD}$ microbiota composition remained unchanged [56].

By comparing the data on individual phenol content (Table 4) with the experimented methane production values (Figure 3) threshold concentrations of T and HT could be established after which the AD process may be inhibited. Although there are other inhibitors that can affect AD, specifically, HT and T concentrations equal to or lower than $582 \mathrm{mg} / \mathrm{L}$ and $198 \mathrm{mg} / \mathrm{L}$ cannot be considered as inhibitors of the AD process because these concentrations did not significantly affect methane production. These concentrations of $\mathrm{HT}$ and $\mathrm{T}$ were reached in A1 pretreatment, which was the pretreatment with the highest methane yield, reaching $383 \pm 2 \mathrm{~mL} \mathrm{CH}_{4} / \mathrm{g} \mathrm{VS}_{\text {added, }}$.

The most remarkable data was that there was no presence of degradation products such as hydroxymethylfurfural or furfural, which are among the main inhibitors for AD [25], although furfural could have been lost because of its volatility [57].

\subsection{Effect of SHP on AD rate and methane yield}


Figure 3 shows the methane production of different pre-treated OMSWs and untreated OMSW over a period of 30 days. The methane yield obtained during AD of $100 \% \mathrm{OMSW}$ was $341 \pm 22 \mathrm{~mL} \mathrm{CH}_{4} / \mathrm{g} \mathrm{VS}$ added. This value of methane yield obtained for the BMP test of OMSW was in accordance with previous studies [3, 41, 58]. After 30 days of experiment, the maximum methane yield obtained was $383 \pm 2 \mathrm{~mL}$ $\mathrm{CH}_{4} / \mathrm{g} \mathrm{VS}_{\text {added }}$ for A1 pre-treatment. The A2 pre-treatment obtained $352 \pm 8 \mathrm{~mL} \mathrm{CH}_{4} / \mathrm{g} \mathrm{VS}_{\text {added }}$, and finally, A3 produced $315 \pm 10 \mathrm{~mL} \mathrm{CH}_{4} / \mathrm{g} \mathrm{VS}_{\text {added }}$. By contrast, B pre-treatments reached values of $308 \pm$ 39, $290 \pm 16$ and $274 \pm 6 \mathrm{~mL} \mathrm{CH}_{4} / \mathrm{g} \mathrm{VS}_{\text {added }}$ for B1, B2 and B3, respectively. Therefore, only the pretreatments A1 and A2 exhibited higher methane yields compared to the AD of untreated OMSW. Thus, the experimental methane yield improvement was $12.3 \%$ and $3.2 \%$ for A1 and A2, respectively.

Many authors have pointed out a high increase in methane yield as one of the benefits of the pretreatments, but sometimes the solubilization of organic matter is not so good for the ultimate methane yield. Hydrothermal pretreatments can also cause the formation of undesirable compounds, leading to a reduced biomethane production $[59,60]$. For instance, in this study the pre-treatment which solubilized more organic matter was B1 $\left(133^{\circ} \mathrm{C}, 2.1 \mathrm{bar}, 30 \mathrm{~min}\right)$, but it showed a methane yield which was lower than that obtained for untreated biomass. By contrast, A1, which only increased the organic matter solubilization by $10 \%$, showed a markedly higher methane yield compared to the untreated substrate probably due to that A1 was the pretreatment that solubilized more polysaccharides.

On the other hand, B pre-treatment modified the kinetics of OMSW degradation, but finally, the methane yield was $15 \%$ less than that obtained from the untreated OMSW [49].

Exposure to high temperature and high pressure during hydrothermal pre-treatment could therefore account for a significantly lower polysaccharide and phenol solubilization due to the fact that both are degraded in other molecules, although furfural o 5-HMF was not found in this case. By comparing the data on individual phenol content (Table 4) with the experimented methane production values (Figure 3) threshold concentrations of $\mathrm{T}$ and HT could be established after which the AD process may be inhibited. Specifically, HT and T concentrations (in the BMP bottles) equal to or lower than $582 \mathrm{mg} / \mathrm{L}$ and 198 $\mathrm{mg} / \mathrm{L}$ cannot be considered as inhibitors of the $\mathrm{AD}$ process because these concentrations did not significantly affect methane production. Lower and higher HT and T values were obtained for A2, A3 and B pretreatments, respectively. Methane yield values of A2, A3 and B pretreatments were lower than those obtained after A1 pretreatment AD. A1 was the pretreatment with the highest methane yield, reaching $383 \pm 2 \mathrm{~mL} \mathrm{CH} 4 / \mathrm{g} \mathrm{VS}_{\text {added }}$. These threshold concentrations of $\mathrm{T}$ and HT are in accordance with 
Pourier et al., [56]. They studied the phenolic compounds effect on AD and on the microbiota concluding that when phenolic compounds were at concentrations less than $0.50 \mathrm{~g} / \mathrm{L}$, optimized AD performance was preserved regardless initial phenol concentration and AD microbiota composition remained unchanged [56].

The most remarkable data was that there was no presence of degradation products such as hydroxymethylfurfural or furfural, which are among the main inhibitors for AD [28], although furfural could have been lost because of its volatility [57].

\subsection{PEC and PCA analysis}

In order to link up the effect of pre-treatment and the methane production, a PEC was carried out. A positive correlation was observed between methane and the $\mathrm{Va}(\mathrm{r}=0.343)$ and a negative correlation with sCOD $(r=-0.519)$ and with the $\mathrm{T}(\mathrm{r}=-0.340)$. The other phenols (HT, Glu-HT, V and DHPG), soluble polysaccharides and the fiber size did not demonstrate a high correlation with methane production.

PCA analysis of the biochemical composition of the substrates after SHPs shows that nearly $95 \%$ of variability could be explained by the first three principal components (Figure 4). The first principal component (PC1) expressed $66.81 \%$ of the overall variance. The second (PC2) and the third (PC3) principal component expressed 14.64 and 12.83\%, respectively. All parameters (phenols, polysaccharides and sCOD) except methane were positioned close to PC1. Instead, they were opposed to fiber length and diameter. PC2 were close to the Va. The correlated polysaccharides (arabinose, xylose, galactose and glucose) and fiber length and diameter were also clustered in the direction of PC2 but with negative coordinates. PC3 was positive connected with sCOD and negative with Va, glucose and methane (Figure 4).

A1 and A2 samples that reached the highest methane yield $\left(380 \pm 5\right.$ and $350 \pm 6 \mathrm{ml} \mathrm{CH}_{4} / \mathrm{g} \mathrm{VS}_{\text {added }}$, respectively) were gathered together and can be explained by the polysaccharides of content in glucose, arabinose, xylose, galactose and the Va. B pre-treatments, the lowest methane yield, were linked with sCOD and the $\mathrm{T}$.

\subsection{Effect of SHP on process kinetics}

Table 5 shows the main performance and kinetic parameters obtained from the application of the TF model to the experimental data of methane production-time corresponding to the different BMPs or tests 
carried out. As can be seen, the high $\mathrm{R}$ and $\mathrm{R}^{2}$ values as well as the low values of errors and standard errors of estimates $\left(\sigma_{\text {est }}\right)$ indicated that the experimental data correctly fit the proposed model.

As can be seen in Table 5, for the thermal pre-treatment carried out at 1.1 bar pressure and $121{ }^{\circ} \mathrm{C}$ temperature (experimental serie A), the theoretical ultimate methane yield increased from $306 \pm 3 \mathrm{~mL}$ $\mathrm{CH}_{4} / \mathrm{g} \mathrm{VS}_{\text {added }}$ (A3) to $380 \pm 5 \mathrm{~mL} \mathrm{CH}_{4} / \mathrm{g} \mathrm{VS}_{\text {added }}$ (A1) when the exposure time during pre-treatment augmented from 15 to 30 minutes. This represents a $24.2 \%$ increase when the operation time increased between the above-mentioned values. This increase was statistically significant with a probability level of $95 \%$. In the same way, for the experiments performed at 2.1 bar pressure and $133{ }^{\circ} \mathrm{C}$ (experimental serie B), the predicted ultimate methane yield also increased significantly from $270 \pm 4 \mathrm{~mL} \mathrm{CH}_{4} / \mathrm{g} \mathrm{VS}_{\text {added }}(\mathrm{B} 3)$ to $296 \pm 3 \mathrm{~mL} \mathrm{CH}_{4} / \mathrm{g} \mathrm{VS}_{\text {added }}$ (B1) when the operation time during pre-treatment increased from 15 to 30 minutes. Therefore, an increase of only $9.6 \%$ was appreciated in this case. Moreover, in the experimental series B, all predicted methane yield values were lower than the ultimate methane yields obtained during the experimental series A and also lower than that obtained for untreated OMSW. The same trend was observed with the experimental values for methane yield.

Among the different experimental conditions tested, only the experiment A1 gave either the predicted and experimental ultimate methane yields higher than that obtained for untreated OMSW. Therefore, the operational conditions for pre-treatment A1 allowed for obtaining a substrate with an anaerobic biodegradability higher than that obtained from the untreated OMSW. This resulted in an increase of $6.1 \%$ in the methane yield of the pre-treated OMSW at the above conditions (A1) compared to untreated OMSW. This fact can be attributed to the significantly higher polysaccharides and phenols solubilisation present in the OMSW pre-treated at these conditions (A1) compared to untreated OMSW. The polysaccharide and phenol solubilisation values observed after A1 pre-treatment did not inhibit the anaerobic digestion process. Momayez et al. [61] described an enhancement of up to $26 \%$ in methane production in the $\mathrm{AD}$ from thermally pre-treated rice straw $\left(190^{\circ} \mathrm{C}, 30\right.$ minutes $)$.

Potent $\mathrm{AD}$ inhibitors can be formed after thermally pre-treated lignocellulosic biomass [62-63]. Sometimes the solubilization of organic matter through thermal pre-treatment is not so good for the ultimate methane yield [59-60]. In fact, the methane yields obtained in the BMP tests of untreated and autoclaved food waste were 0.501 and $0.445 \mathrm{~m}^{3} \mathrm{CH}_{4} / \mathrm{kg}$ VS, respectively, which were probably due to the formation of refractory compounds such as melanoidins, that can affect biodegradability and, consequently, methane production [64]. 
The calculated lag times $(\mathcal{C})$ were found to be zero in all cases, because the easy and most available biodegradable components of all substrates were quickly consumed in all the AD processes studied [40]. The $R_{\max }$ values presented a somewhat different trend to that observed for $B_{\max }$ in the different experiments carried out. The highest $R_{\max }$ value was found for the experiment A3 with $102 \pm 5 \mathrm{~mL} \mathrm{CH}_{4} / \mathrm{g}$ VS.d. This value was $45.7 \%$ higher compared to that obtained for untreated OMSW $(70 \pm 5 \mathrm{~mL} \mathrm{CH} / \mathrm{g}$ VS.d). It has been recently reported that the performance of thermal pre-treatment is influenced by both temperature and exposure time [65] and the optimal temperature depends on the substrate characteristics. On the contrary, the slowest biomethanization process took place for the B3 conditions. This decrease in $R_{\max }$ for the pre-treatment carried out at higher temperature and pressure conditions is a good indication that compounds in this pre-treated fraction might have a lower initial availability for its AD [63]. In addition, a higher temperature in the pre-treatment could derive in the degradation of some complex phenolic compounds to undesirable compounds such as low-molecular weight phenolic compounds, which have been considered as inhibitory for AD processes at certain concentrations [62-63].

\section{CONCLUSIONS}

The SHP A1 $\left(121^{\circ} \mathrm{C}, 1.1\right.$ bar for 30 minutes of exposure time) increased the methane yield of the pretreated OMSW by $12.3 \%$ compared to the value obtained for untreated OMSW. However, the A1 pretreatment did not generate the maximum solubilization of the waste, which was achieved in the B3 pretreatment $\left(133{ }^{\circ} \mathrm{C}, 2.1\right.$ bar for 15 minutes). The SHPs helped to break the OMSW fiber in half both in length and in diameter, helping to solubilize sugars in the form of polysaccharides. The pre-treatments also helped to solubilize phenolic compounds achieving high concentrations of valuable compounds such as HT, $658.9 \pm 0.8 \mathrm{mg} / \mathrm{L}$, and DHPG, $405.4 \pm 0.4 \mathrm{mg} / \mathrm{L}$, moreover, some of them being beneficial for the $\mathrm{AD}$ process at the concentration ranges tested $(7.3 \mathrm{mg} / \mathrm{L}$ for vanillic acid). However, it was found that $\mathrm{T}$ concentrations higher than $198 \mathrm{mg} / \mathrm{L}$ were inhibitory for the AD process, bringing about a decrease in methane production. The Transference Function (TF) model was demonstrated to be a proper tool for evaluating the performance and kinetic parameters of the AD of thermally-pre-treated OMSW. The A1 thermal pre-treatment conditions allowed for increasing the predicted methane yield by $6.1 \%$ compared to untreated OMSW. The highest value for maximum methane production rate, $R_{\max }$, was obtained at the above-mentioned conditions but at $15 \mathrm{~min}$ of exposure time (A3). 


\section{REFERENCES}

[1] COI (2018) http://www.internationaloliveoil.org/estaticos/view/131-world-olive-oilfigures?lang=es_ES.Consejo Oleícola Internacional.

[2] AICA, 2016. Informe de AICA sobre el mercado del aceite de oliva y el de la aceituna de mesa (campaña 2015/2016). Agencia de Información y Control Alimentarios. Ministerio de Agricultura, Alimentación y Medio Ambiente. España. Febrero, 2016.

[3] B. Rincón, L. Bujalance, F.G. Fermoso, A. Martín, R. Borja, Biochemical methane potential of two-phase olive mill solid waste: Influence of thermal pretreatment on the process kinetics. Bioresour. Technol., 140 (2013), 249-255, https://doi.org/ 10.1016/j.biortech.2013.04.090

[4] J.C. Motte, R. Escudié, N. Beaufils, J.P. Steyer, N. Bernet, J.P. Delgenès, C. Dumas, Morphological structures of wheat straw strongly impacts its anaerobic digestion. Ind. Crop. Prod., 52 (2014), 695-701, https://doi.org/10.1016/j.indcrop.2013.11.038

[5] M. Zala, R. Solanki, P.V. Bhale, S. Vaishak, Experimental investigation on anaerobic codigestion of food waste and water hyacinth in batch type reactor under mesophilic condition. Biomass Convers. Biorefinery, (2019). In Press https://doi.org/10.1007/s13399-019-00522-1

[6] R. Borja, B. Rincón, F. Raposo, Anaerobic biodegradation of two-phase olive mill solid wastes and liquid effluents: kinetic studies and process performance. J. Chem. Technol. Biotechnol., 81(9) (2006) 1450-1462, https://doi.org/10.1002/jctb

[7] W. Maamir, Y. Ouahabi, S. Poncin, H.-Z. Li, K. Bensadok, Effect of Fenton pretreatment on anaerobic digestion of olive mill wastewater and olive mill solid waste in mesophilic conditions. Int. J. Green Energy 14 (2017) 555-560.

[8] A. Gianico, C.M. Braguglia, D. Mescia, G. Mininni, Ultrasonic and thermal pretreatments to enhance the anaerobic bioconversion of olive husks. Bioresour. Technol. 147 (2013) 623-626, doi:https://doi.org/10.1016/j.biortech.2013.08.054.

[9] B. Ruggeri,F. Battista, M. Bernardi, D. Fino, G. Mancini, The selection of pretreatment options for anaerobic digestion (AD): A case study in olive oil waste production. Chem. Eng. J. 259 (2015) 630-639, doi:https://doi.org/10.1016/j.cej.2014.08.035.

[10] H. Carrere, G. Antonopoulou, R. Affes, F. Passos, A. Battimelli, G. Lyberatos, I. Ferrer, Review of feedstock pretreatment strategies for improved anaerobic digestion: From lab-scale research to full-scale application. Bioresour. Technol., $199 \quad$ (2016) 386-397, https://doi.org/10.1016/j.biortech.2015.09.007.

[11] J. Kainthola, M. Shariq, A. S.Kalamdhad, V.V. Goud, Comparative study of different thermal pretreatment techniques for accelerated methane production from rice Straw. Biomass Convers. Biorefinery, (2019). In Press https://doi.org/10.1007/s13399-019-00537-8 
[12] D. Jackowiak, J.C. Frigon, T. Ribeiro, A. Pauss, S. Guiot, Enhancing solubilisation and methane production kinetic of switchgrass by microwave pretreatment. Bioresour. Technol. 102 (2011) 3535-3540, https://doi.org/10.1016/j.biortech.2010.11.069

[13] S. Pansripong W. Arjharn P. Liplap T. Hinsui, Effect of Ultrasonic Pretreatment on Biogas Production from Rice Straw. Orient J Chem 4 (2019) 35.

[14] S.Y. Jeong, J.W. Lee, Chapter 5 - Hydrothermal Treatment, in: Pandey, A., Negi, S., Binod, P., Larroche, C. (Eds.), Pretreatment of Biomass. Elsevier, Amsterdam, (2015) 61-74.

[15] G. Garrote, H. Domínguez, J. Parajó, Hydrothermal processing of lignocellulosic materials. Holz als Roh- und Werkstoff., 57(3) (1999) 191-202, https:// doi.org/10.1007/s001070050039

[16] K. Ziemiński, I. Romanowska, M. Kowalska-Wentel, M. Cyran, Effects of hydrothermal pretreatment of sugar beet pulp for methane production, Bioresour. Technol., 166 (2014) 187193, https://doi.org/ 10.1016/j.biortech.2014.05.02

[17] M.S.R. Dos Santos Rocha, B. Pratto, R. de Sousa Júnior, R.M.R. García Almeida, A.J.G.D. Cruz, A kinetic model for hydrothermal pretreatment of sugarcane Straw, Bioresour. Technol., 228 (2017) 176-185, https://doi.org/10.1016/j.biortech.2016.12.087

[18] H. Abu Tayeh, O. Levy-Shalev, H. Azaizeh, C.G. Dosoretz, Subcritical hydrothermal pretreatment of olive mill solid waste for biofuel production, Bioresour. Technol., 199 (2016) 164-172, https://doi.org/10.1016/j.biortech.2015.08.138

[19] X. Jia, B. Xi, M. Li, D. Liu, J. Hou, Y. Hao, F. Meng, Metaproteomic analysis of the relationship between microbial community phylogeny, function and metabolic activity during biohydrogenmethane coproduction under short-term hydrothermal pretreatment from food waste, Bioresour. Technol., 245 (2017) 1030-1039, https://doi.org/10.1016/j.biortech.2017.08.180

[20] N. Ibrahim, M.S. Yusoff, H.A. Aziz, Food waste characteristics after autoclaving treatment.2nd International Conference on Biotechnology and Food Science. IPCBEE, IACSIT, Press. Singapore, (2011), vol. 7.

[21] I. Pecorini, F. Baldi, E.A. Carnevale, A. Corti, Biochemical methane potential tests of different autoclaved and microwaved lignocellulosic organic fractions of municipal solid waste, Waste Manage. (Oxford), 56 (2016) 143-150, https://doi.org/10.1177/0734242X15622815

[22] M. Kim, B.C. Kim, K. Nam, Y. Choi, Effect of pretreatment solutions and conditions on decomposition and anaerobic digestion of lignocellulosic biomass in rice straw, Biochem. Eng. J., 140 (2018) 108-114, https://doi.org/10.1016/j.bej.2018.09.012

[23] C. Bougrier, J.P. Delgenès, H. Carrère, Effects of thermal treatments on five different waste activated sludge samples solubilisation, physical properties and anaerobic digestion, Chem. Eng. J. 139 (2) (2008) 236-244, https://doi.org/ 10.1016/j.cej.2007.07.099

[24] B. Ruffino, G. Campo, G. Genon, E. Lorenzi, D. Novarino, G. Scibilia, M. Zanetti, Improvement of anaerobic digestion of sewage sludge in a wastewater treatment plant by means of mechanical and thermal pre-treatments: Performance, energy and economical assessment. Bioresour. Technol., 175 (2015), 298-308. 
[25] F. Monlau, A. Barakat, J.P. Steyer, Comparison of seven types of thermo-chemical pretreatments on the structural features and anaerobic digestion of sunflower stalks, Bioresour. Technol., 120 (2012) 241-247, https://doi.org/10.1016/j.biortech.2012.06.040

[26] S.I. Mussatto, I.C. Roberto, Alternatives for detoxification of diluted-acid lignocellulosic hydrolyzates for use in fermentative processes: a review, Bioresour. Technol., 93(1) (2004) 1-10, https://doi.org/ 10.1016/j.biortech.2003.10.005

[27] M. Quéméneur, J. Hamelin, A. Barakat, J.P. Steyer, H. Carrere, E. Trably, Inhibition of fermentative hydrogen production by lignocellulose-derived compounds in mixed cultures, Int. J. Hydrogen Energy, 37(4) (2012), 3150-3159, https://doi.org/ 10.5483/BMBRep.2013.46.5.038

[28] F. Monlau, C. Sambusiti, A. Barakat, M. Quéméneur, E. Trably, J.P. Steyer, H. Carrère, Do furanic and phenolic compounds of lignocellulosic and algae biomass hydrolyzate inhibit anaerobic mixed cultures? A comprehensive review, Biotechnol. Adv., 32(5) (2014) 934-951, https://doi.org/ 10.1016/j.biotechadv.2014.04.007

[29] B. Kumar Biswal, H. Huang, J. Dai, G.H. Chen, D. Wu, Impact of low-thermal pretreatment on physicochemical properties of saline waste activated sludge, hydrolysis of organics and methane yield in anaerobic digestion. Bioresour. Technol. 297 (2020) 122423.

[30] F. Raposo, M.A. de la Rubia, R. Borja, M. Alaiz, Assessment of a modified and optimised method for determining chemical oxygen demand of solid substrates and solutions with high suspended solid content, Talanta, 76(2) (2008) 448-453, https://doi.org/ 10.1016/j.talanta.2008.03.030

[31] APHA-AWWA-WEF, 2005. Standard Methods for the Examination of Water and Wastewater (22nd edn.), American Water Works Association, Washington, DC twentieth edition, Washington, DC.

[32] Norm UNE-EN-ISO 5351:2004

[33] Norm UNE 55-032-073

[34] IUPAC, 1992. Standard methods for the analysis of oils, fats and derivatives, first supplement to 7th ed. International union of pure and applied chemistry, Oxford: Blackwell.

[35] O. Folin, V. Ciocalteu, On Tyrosine and Tryptophane Determinations in Proteins, J. Biol. Chem., 73 (1927) 627-650

[36] J.M. De Ruiter, J.C. Burns. Characterization of trifluoroacetic acid hydrolyzed subtropical forage grass cell walls, J. Agric. Food. Chem., 35(3) (1987) 308-316, https://doi.org/ 10.1021/jf00075a006

[37] H.N. Englyst, J.H. Cummings, Simplified method for the measurement of total non-starch polysaccharides by gas-liquid chromatography of constituent sugars as alditol acetates, Analyst., 109(7) (1984) 937-942.

[38] Z. Dische, Color reactions of carbohydrates. In Methods in carbohydrate chemistry. In: R.L. Whistler, M.L. Wolfram, (Eds.), Academic Press: New York, (1962) 477-512, https://doi.org/ 10.1021/ed040pA394 
[39] A. Donoso-Bravo, S.I. Perez-Elvira, F. Fernández-Polanco, Application of simplified models for anaerobic biodegradability tests. Evaluation of pre-treatment processes, Chem. Eng. J., 160 (2010) 607-614, https://doi.org/ 10.1016/j.cej.2010.03.082

[40] L. Li, X. Kong, F. Yang, D. Li, Z. Yuan, Y. Sun, Biogas production potential and kinetics of microwave and conventional thermal pretreatment of grass, Appl. Biochem. Biotechnol., 166 (2012) 1188-1191, https://doi.org/ 10.1007/s12010-011-9503-9

[41] M.J. Fernández-Rodríguez, D. De la Lama-Calvente, A. Jiménez-Rodríguez, R. Borja, B. Rincón-Llorente. Influence of the cell wall of Chlamydomonas reinhardtii on anaerobic digestion yield and on its anaerobic co-digestion with a carbon-rich substrate, Process Safety and Environmental Protection, 128 (2019), 167-175. https://doi.org/10.1016/j.psep.2019.05.041

[42] I.T. Jollife, J. Cadima, Principal component analysis: A review and recent developments. Philosophical Transactions of the Royal Society A: Mathematical, Phys. Eng. Sci., 374 (2065) (2016) https://doi.org/10.1098/rsta.2015.0202

[43] R Core Team. R: A language and environment for statistical computing. R Foundation for Statistical Computing, Vienna, Austria. (2019) https://www.R-project.org/.

[44] H. Şenol, Ü. Açıkel, S. Demir, V. Oda, Anaerobic digestion of cattle manure, corn silage and sugar beet pulp mixtures after thermal pretreatment and kinetic modeling study. Fuel 263 (2020) 116651, doi:https://doi.org/10.1016/j.fuel.2019.116651.

[45] S. Kassaye, K.K. Pant, S. Jain, Hydrolysis of cellulosic bamboo biomass into reducing sugars via a combined alkaline solution and ionic liquid pretreament steps, Renew. Energy, 104 (2017) 177-184. https://doi.org/ 10.1016/j.renene.2016.12.033

[46] S. Vecchio, L. Campanella, A. Nuccilli, M. Tomassetti, Kinetic study of thermal breakdown of triglycerides contained in extra-virgin olive oil, J. Therm. Anal. Calorim., 91 (2008) 51-56, https://doi.org/ 10.1007/s10973-007-8373-4

[47] P. Sannigrahi, D.H. Kim, S., Jung, A. Ragauskas, Pseudo-lignin and pretreatment chemistry, Energy Environ. Sci., 4 (2011) 1306-1310, https://doi.org/ 10.19080/RAPSCI.2017.01.555551

[48] M.E. Alzate, R. Muñoz, F. Rogalla, F. Fdz-Polanco, S.I. Pérez-Elvira, Biochemical methane potential of microalgae: Influence of substrate to inoculum ratio, biomass concentration and $\begin{array}{llll}\text { pretreatment, } & \text { Bioresour.Technol., } & 123 & \text { (2012) }\end{array}$ https://doi.org/10.1016/j.biortech.2012.06.113

[49] A. Barakat, F. Monlau, J.P. Steyer, H. Carrere, Effect of lignin-derived and furan compounds found in lignocellulosic hydrolysates on biomethaneproduction, Bioresour. Technol., 104 (2012) 90-9, https://doi.org/ 10.1016/j.biortech.2011.10.060

[50] E. Christoforou, P.A. Fokaides, A review of olive mill solid wastes to energy utilization techniques, Waste Manage., (Oxford). 49 (2016) 346-363. https://doi.org/ 10.1016/j.wasman.2016.01.012

[51] C. Zhang, C.J. Houtman, J.I. Zhu, Using low temperature to balance enzymatic saccharification and furan formation during SPORL pretreatment of Douglas-fir, Process Biochem., 49(3) (2014) 466-473, https://doi.org/10.1016/j.procbio.2013.12.017 
[52] M. Abdessalem, A. García-Borrego, A. Jiménez-Araujo, J. Fernández-Bolaños, M. Sindic, G. Rodríguez-Gutiérrez, Phelonic extracts obtained from thermally treated secondary varietes of dates: Antimicrobial and antioxidant properties, LWT-Food Sci. Technol., 79 (2017) 416-422, https://doi.org/10.1016/j.lwt.2017.01.064

[53] F. Rubio-Senent, G. Rodríguez-Gutiérrez, A. Lama-Muñoz, J. Fernández-Bolaños, Phenolic extract obtained from steam-treated olive oil waste: Characterization and antioxidant activity, Food Sci. Technol. Int., 54(1) (2013) 114-124, https://doi.org/ 10.1021/jf303772p

[54] B. Umamaheswari, R. Rajaram, High strength phenol degradation by CSMB4 at microaerophilic condition, Int. J. Curr. Microbiol. App. Sci., 3(9) (2014) 847-860.

[55] F. Rubio-Senent, G. Rodríguez-Gutiérrez, A. Lama-Muñoz, J. Fernández-Bolaños, New Phenolic Compounds Hydrothermally Extracted from the Olive Oil Byproduct Alperujo and Their Antioxidative Activities, J. Agric. Food. Chem., 60(5) (2012) 1175-1186, https://doi.org/ 10.1021/jf204223

[56] S. Poirier, A. Bize, C. Bureau, T. Bouchez, O. Chapleur, Community shifts within anaerobic digestion microbiota facing phenol inhibition: Towards early warning microbial indicators? Water R. 100 (2016) 296-305.

[57] S. Bolado-Rodríguez, C. Toquero, J. Martín-Juárez, R. Travaini, P.A. García-Encina, Effect of thermal, acid, alkaline and alkaline peroxide pretreatments on the biochemical methane potential and kinetics of the anaerobic digestion of wheat straw and sugarcane bagasse, Bioresour. Technol., 201 (2016) 182-190.

[58] M.J. Fernández-Rodríguez, D. de la Lama-Calvente, A. Jiménez-Rodríguez, R. Borja, B. Rincón-Llorente, Anaerobic co-digestion of olive mill solid waste and microalga Scenedesmus quadricauda: effect of different carbon to nitrogen ratios on process performance and kinetics. J. Appl. Phycol. 31(2019) 3583-3591.

[59] J. Lizasoain, M. Rincón, F. Theuretzbacher, R. Enguidanos, P.J. Nielsen, A. Potthast, T. Zweckmair, A. Gronauer, A. Bauer, Biogas production from reed biomass: effect of pretreatment using different steam explosion conditions, Biomass Bioenergy, 95 (2016) 84-91, https://doi.org/ 10.1016/j.biombioe.2016.09.021

[60] A.S. Razavi, E. Hosseini Koupaie, A. Azizi, H. Hafez, E. Elbeshbishy, Hydrothermal pretreatment of source separated organics for enhanced solubilization and biomethane recovery, Bioresour. Technol., 274 (2019) 502-511, https://doi.org/10.1016/j.biortech.2018.12.024

[61] F. Momayez, K. Karimi, I.S. Horváth, Enhancing ethanol and methane production from rice straw by pretreatment with liquid waste from biogas plant, Energy Convers Manag., 178 (2018) 290-298, https://doi.org/10.1016/j.enconman.2018.10.023

[62] D.S.M. Ghasimi, K. Aboudi, M. De Kreuk, M.H. Zandvoort, J.B. Van Lier, Impact of lignocellulosic-waste intermediates on hydrolysis and methanogenesis under thermophilic and mesophilic conditions, Chemical. Eng. J., $295 \quad$ (2016) 181-191, https://doi.org/10.1016/j.cej.2016.03.045

[63] S. Paul, A. Dutta, Challenges and opportunities of lignocellulosic biomass for anaerobic digestion, $\quad$ Resour. $\quad$ Conserv. $\quad$ Recy., $130 \quad$ (2018) 164-174, https://doi.org/10.1016/j.resconrec.2017.12.005 
[64] P. Pagliaccia, A. Gallipoli, A. Gianico, D. Montecchio, C.M. Braguglia, Single stage anaerobic bioconversion of food waste in mono and co-digestion with olive husks: Impact of thermal pretreatment on hydrogen and methane production, Int. J. Hydrogen Energy, 41(2) (2016) 905915, https://doi.org/10.1016/j.ijhydene.2015.10.061

[65] S. Jain, S. Jain, I.T. Wolf, J. Lee, Y.W. Tong, A comprehensive review on operating parameters and different pretreatment methodologies for anaerobic digestion of municipal solid waste, Renew. Sustain. Energy Rev., 52 (2015) 142-154, https://doi.org/ 10.1016/j.rser.2015.07.091 


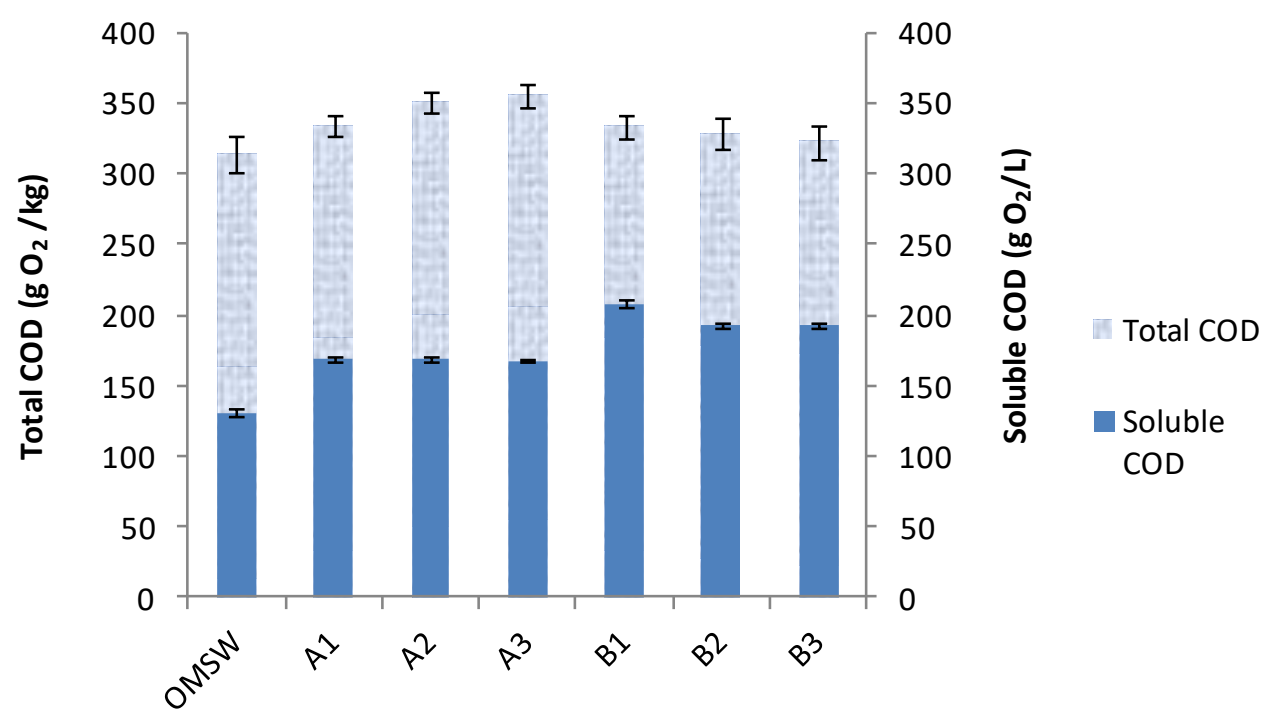

Fig. 1 Total chemical Oxygen Demand (tCOD) and Soluble Chemical Oxygen Demand (sCOD) values for untreated olive mill solid waste (OMSW) and pre-treated OMSW after six different pre-treatments: A1, A2, A3, B1, B2 and B3. Pre-treatment A was carried out at $121^{\circ} \mathrm{C}$ and pressure of 1.1 bar for 30,20 and $15 \min$ (A1, A2 and $\mathrm{A} 3$, respectively), pre-treatment $\mathrm{B}$ was performed at $133^{\circ} \mathrm{C}$ and 2.1 bar for 30,20 and 15 min (B1, B2 and B3, respectively). Each experiment was carried out in triplicate. 


\section{Arabinose}

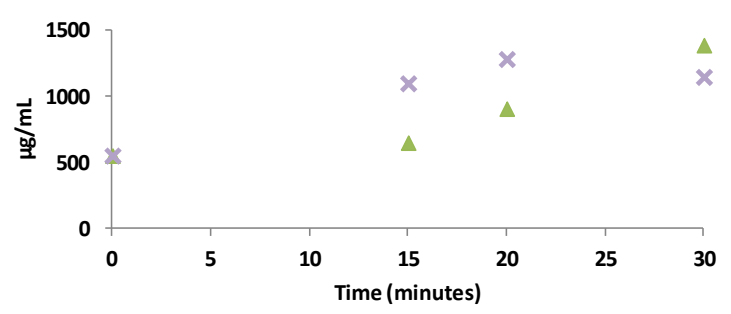

\section{Galactose}

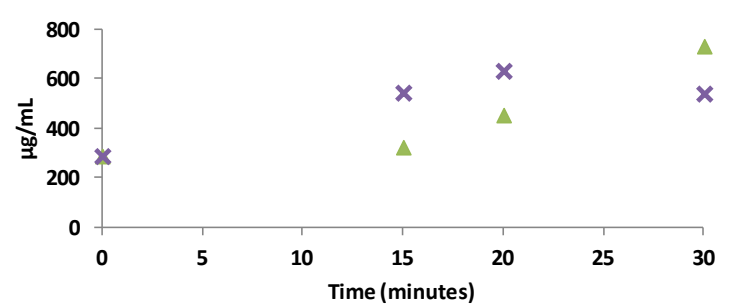

\section{Glucose}

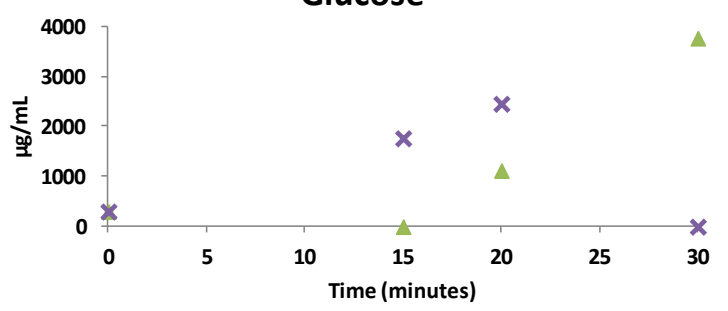

Fucose

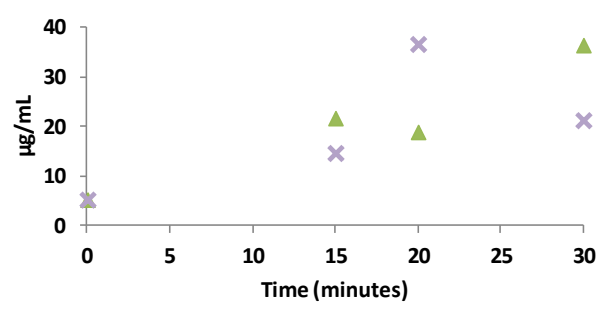

Xylose

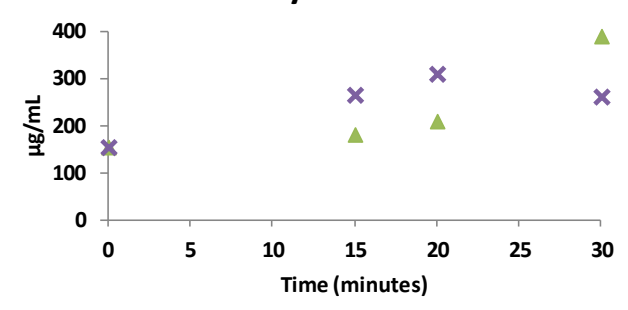

Rhamnose

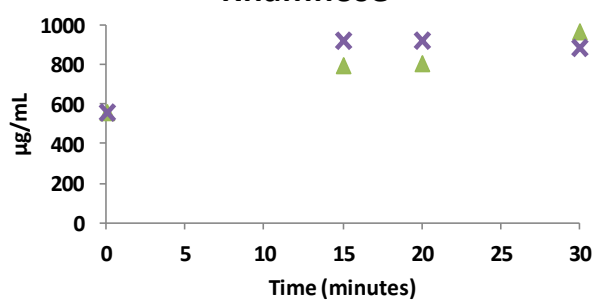

Fig. 2 Variation in polysaccharides concentrations for untreated olive mill solid waste (OMSW) (time $=0)$ and pre-treated OMSW after six different pre-treatments: A1, A2, A3, B1, B2 and B3. Pre-treatment A ( $\mathbf{\Delta})$ was carried out at $121^{\circ} \mathrm{C}$ and pressure of 1.1 bar for 30, 20 and $15 \mathrm{~min}$ (A1, A2 and A3, respectively), pre-treatment B (X) was performed at $133^{\circ} \mathrm{C}$ and 2.1 bar for 30, 20 and 15 min (B1, B2 and B3, respectively) 
a)

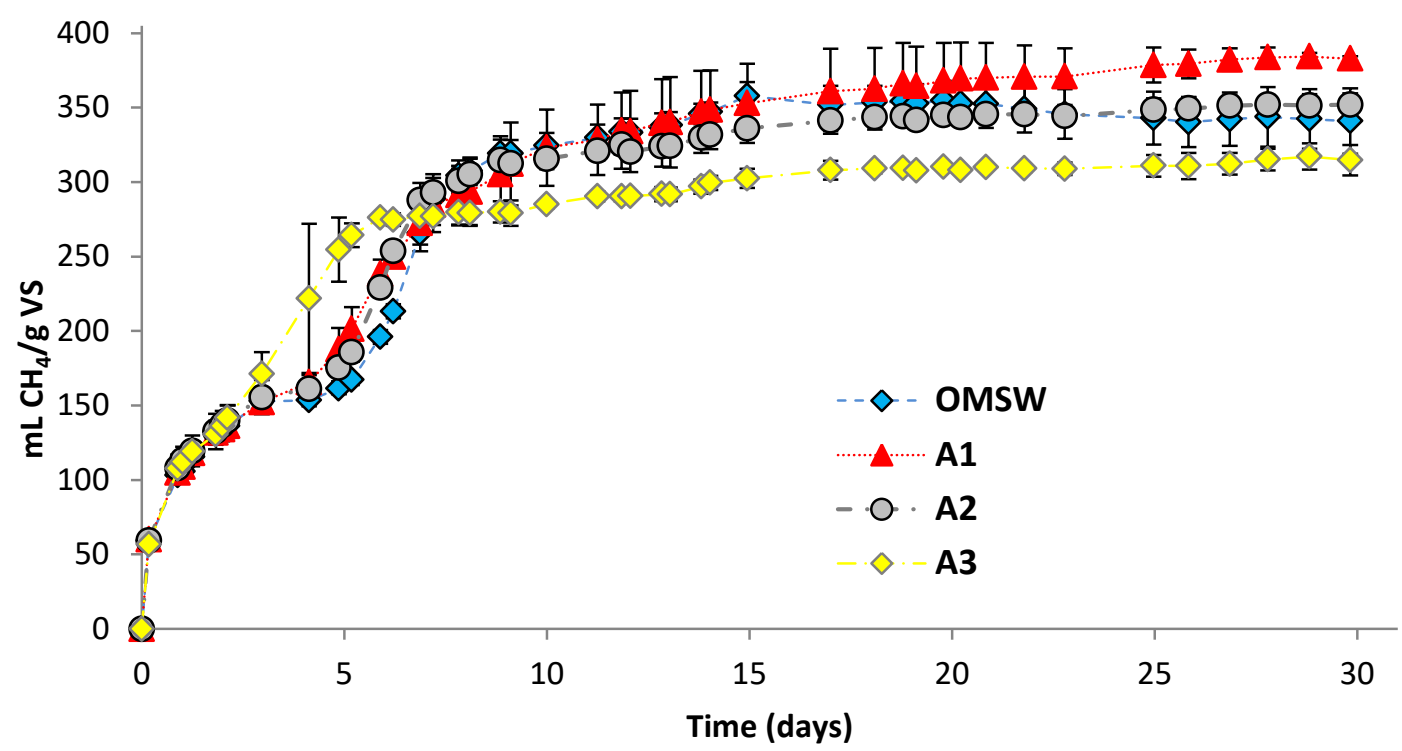

b)

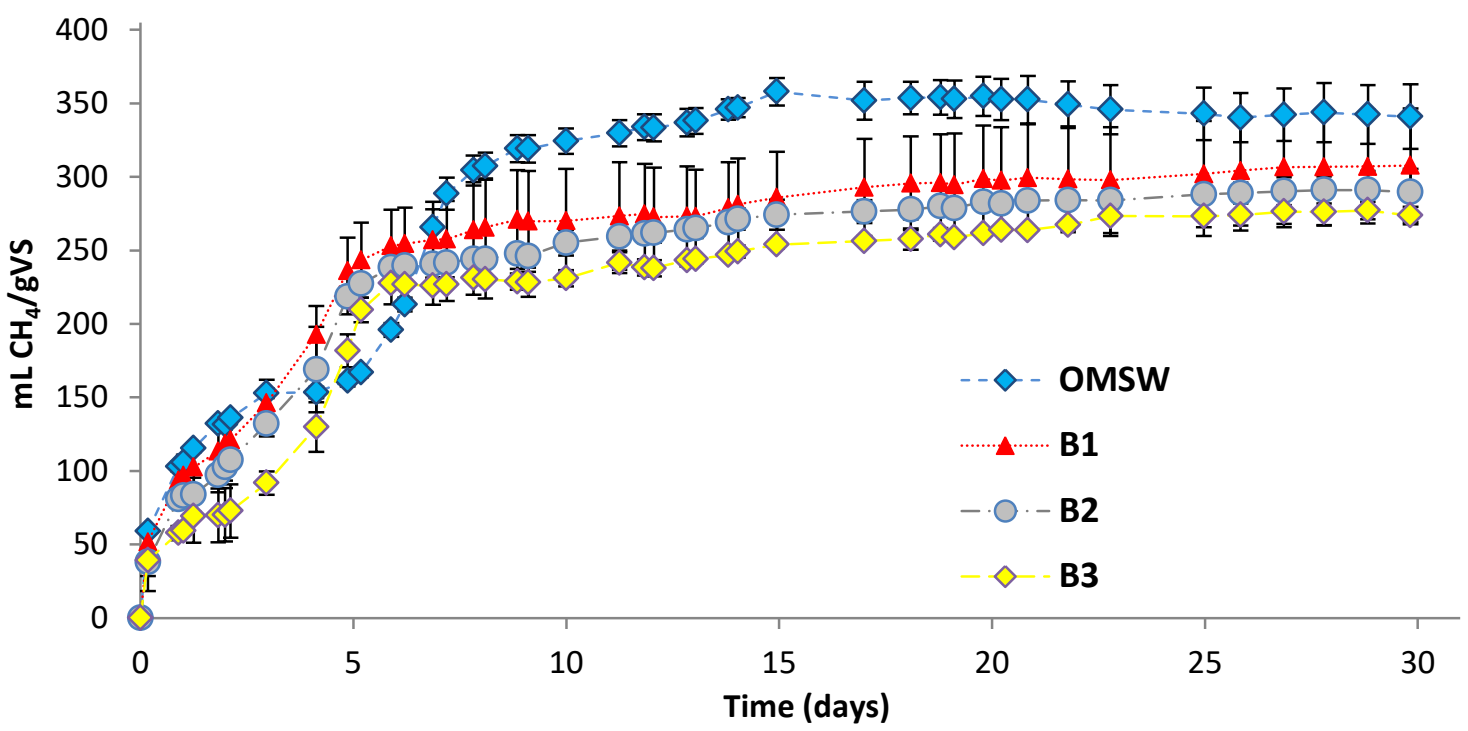

Fig. 3 Cumulative methane yield obtained from untreated olive mill solid waste (OMSW) and pre-treated OMSW after six different pre-treatments: pre-treatment A (Figure (a)) was carried out at $121^{\circ} \mathrm{C}$ and pressure of 1.1 bar for 30, 20 and 15 min (A1, A2 and A3, respectively), pre-treatment B (Figure (b)) was performed at 133 ${ }^{\circ} \mathrm{C}$ and 2.1 bar for 30, 20 and $15 \mathrm{~min}$ (B1, B2 and B3, respectively). Each experiment was carried out in triplicate. 

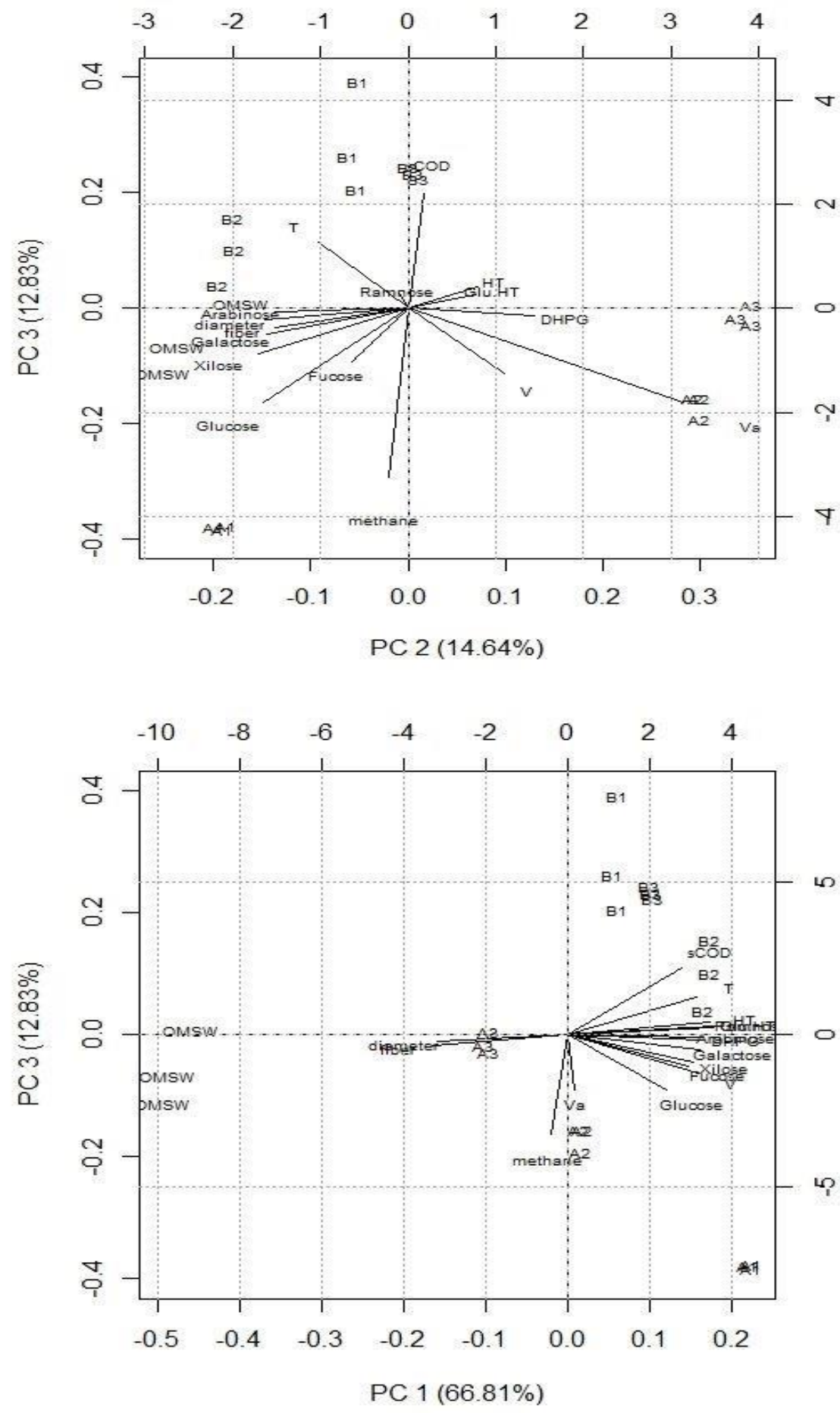

Fig. 4 Principal component analysis of the biochemical composition of the untreated olive mill solid waste (OMSW) and pre-treated OMSW after six different pre-treatments: pre-treatment A was carried out at $121{ }^{\circ} \mathrm{C}$ and pressure of 1.1 bar for 30,20 and 15 min (A1, A2 and $\mathrm{A} 3$, respectively), pre-treatment $\mathrm{B}$ was performed at $133^{\circ} \mathrm{C}$ and 2.1 bar for 30, 20 and $15 \min$ (B1, B2 and B3, respectively). PC1, PC2 and PC3: principal component 1, 2 and 3, respectively 
Table 1. Total lipids, triglycerides, diglycerides and free fatty acid contents of untreated olive mill solid waste (OMSW) and pre-treated OMSW after six different pre-treatments: A1, A2, A3, B1, B2 and B3. Pre-treatment A $121{ }^{\circ} \mathrm{C}$ and 1.1 bar for 30, 20 and 15 min (A1, A2 and A3, respectively) and pre-treatment B was performed at $133^{\circ} \mathrm{C}$ and 2.1 bar for 30,20 and $15 \min (\mathrm{B} 1, \mathrm{~B} 2$ and $\mathrm{B} 3$, respectively).

\begin{tabular}{ccccc}
\hline Substrate & Triglycerides (\%) & Diglycerides (\%) & Free fatty acids (\%) & Total lipids (\%) \\
\hline OMSW & 79.5 & 3.0 & 17.5 & $13.2 \pm 0.4$ \\
A1 & 79.9 & 3.1 & 17.0 & $12.7 \pm 0.2$ \\
A2 & 78.5 & 2.7 & 18.8 & $13.2 \pm 0.4$ \\
A3 & 79.0 & 2.9 & 18.0 & $12.2 \pm 1.1$ \\
B1 & 79.2 & 3.0 & 18.5 & $12.6 \pm 0.5$ \\
B2 & 79.0 & 3.2 & 17.7 & $12.4 \pm 1.2$ \\
B3 & 79.9 & 2.9 & 18.0 & $13.2 \pm 0.1$ \\
\hline
\end{tabular}


Table 2. Fiber analysis for untreated olive mill solid waste (OMSW) and pre-treated OMSW after six different pre-treatments: A1, A2, A3, B1, B2 and B3. Pre-treatment A was carried out at $121{ }^{\circ} \mathrm{C}$ and pressure of $1.1 \mathrm{bar}$ for 30, 20 and 15 min (A1, A2 and A3, respectively), pre-treatment B was performed at $133{ }^{\circ} \mathrm{C}$ and 2.1 bar for 30, 20 and $15 \min$ (B1, B2 and B3, respectively).

\begin{tabular}{|c|c|c|c|c|c|}
\hline Substrates & Length (mm) & $\overline{\text { Diameter }(\mu \mathrm{m})}$ & Ratio (\%) & Fine Elements (\%) & Viscosity (cc/g) \\
\hline OMSW & $0.325 \pm 0.016$ & $49.5 \pm 7.4$ & $3.583 \pm 0.490$ & $99.5 \pm 0.2$ & $44 \pm 2$ \\
\hline A1 & $0.135 \pm 0.004$ & $23.1 \pm 1.1$ & $3.467 \pm 0.432$ & $83.2 \pm 8.7$ & $35 \pm 3$ \\
\hline A2 & $0.139 \pm 0.009$ & $22.6 \pm 0.1$ & $3.760 \pm 0.594$ & $72.1 \pm 8.0$ & $34 \pm 2$ \\
\hline A3 & $0.144 \pm 0.011$ & $23.2 \pm 0.7$ & $4.185 \pm 0.656$ & $63.1 \pm 10.7$ & $35 \pm 3$ \\
\hline B1 & $0.139 \pm 0.005$ & $24.3 \pm 1.5$ & $4.338 \pm 1.150$ & $88.0 \pm 5.2$ & $33 \pm 2$ \\
\hline B2 & $0.143 \pm 0.002$ & $23.3 \pm 1.2$ & $3.929 \pm 0.214$ & $81.3 \pm 5.9$ & $30 \pm 5$ \\
\hline B3 & $0.136 \pm 0.002$ & $24.1 \pm 1.3$ & $3.946 \pm 0.462$ & $85.4 \pm 6.7$ & $34 \pm 1$ \\
\hline
\end{tabular}


Table 3. Concentration of monosacharides $(\mu \mathrm{g} / \mathrm{ml})$ in the soluble phase of untreated olive mill solid waste $(\mathrm{OMSW})$ and in the pre-treated OMSW after six different pre-treatments: A1, A2, A3, B1, B2 and B3. Pretreatment A was carried out at $121^{\circ} \mathrm{C}$ and pressure of 1.1 bar for 30,20 and $15 \min (\mathrm{A} 1, \mathrm{~A} 2$ and $\mathrm{A} 3$, respectively), pre-treatment $\mathrm{B}$ was performed at $133{ }^{\circ} \mathrm{C}$ and 2.1 bar for 30,20 and 15 min (B1, B2 and B3, respectively).

\begin{tabular}{cccccccc}
\hline Substrate & Rhamnose & Fucose & Arabinose & Xylose & Manose & Glucose & Galactose \\
\hline OMSW & $76.3 \pm 4.7$ & $3.8 \pm 0.1$ & $295.4 \pm 8.8$ & $155.5 \pm 1.6$ & $5304 \pm 93$ & $15777 \pm 78$ & $287.1 \pm 9.3$ \\
A1 & $81.5 \pm 9.0$ & $0.2 \pm 0.1$ & $291.6 \pm 10.3$ & $132.4 \pm 7.6$ & $5377 \pm 430$ & $16303 \pm 189$ & $240.5 \pm 5.2$ \\
A2 & $80.0 \pm 6.8$ & $0.5 \pm 0.7$ & $289.9 \pm 3.0$ & $152.5 \pm 7.7$ & $5468 \pm 24$ & $16186 \pm 222$ & $283.6 \pm 13$ \\
A3 & $72.4 \pm 0.7$ & $0.9 \pm 1.2$ & $278.3 \pm 13.4$ & $129.7 \pm 1.9$ & $5275 \pm 173$ & $16368 \pm 116$ & $257.5 \pm 22$ \\
B1 & $115 \pm 1.0$ & $2.9 \pm 0.6$ & $316.3 \pm 4.5$ & $142.4 \pm 16.5$ & $5924 \pm 74$ & $16967 \pm 150$ & $271.7 \pm 7$ \\
B2 & $91.0 \pm 16.1$ & $2.1 \pm 0.3$ & $300.8 \pm 16.3$ & $154.6 \pm 12.2$ & $5706 \pm 273$ & $16448 \pm 701$ & $286.7 \pm 18$ \\
B3 & $89.9 \pm 12.4$ & $1.3 \pm 1.9$ & $318.6 \pm 24.4$ & $155.3 \pm 13.5$ & $5723 \pm 353$ & $16861 \pm 620$ & $286.4 \pm 19$ \\
\hline
\end{tabular}


Table 4. Concentration of the main phenols $(\mathrm{mg} / \mathrm{L})$ in the untreated olive mill solid waste (OMSW) and in the pre-treated OMSW after six different pre-treatments: A1, A2, A3, B1, B2 and B3. Pre-treatment A was carried out at $121^{\circ} \mathrm{C}$ and pressure of 1.1 bar for 30,20 and $15 \min (\mathrm{A} 1, \mathrm{~A} 2$ and $\mathrm{A} 3$, respectively), pre-treatment $\mathrm{B}$ was performed at $133{ }^{\circ} \mathrm{C}$ and 2.1 bar for 30, 20 and $15 \mathrm{~min}$ (B1, B2 and B3, respectively). DHPG: 3,4dihydroxyphenylglycol, HT: hydroxytyrosol, T: tyrosol, Glu-HT: hydroxytytosol-glucoside, V: vanillin and Va: vanillic acid.

\begin{tabular}{ccccccc}
\hline Substrate & DHPG & Glu-HT & HT & T & V & Va \\
\hline OMSW & $22.9 \pm 0.3$ & $126.9 \pm 0.2$ & $40.6 \pm 0.0$ & $142.2 \pm 0.3$ & $122.7 \pm 0.2$ & $9.35 \pm 0.0$ \\
A1 & $405.4 \pm 0.4$ & $295.9 \pm 0.2$ & $582.3 \pm 0.6$ & $198.2 \pm 0.2$ & $296.1 \pm 0.3$ & $17.9 \pm 0.0$ \\
A2 & $371.3 \pm 0.2$ & $275.1 \pm 0.4$ & $588.9 \pm 0.5$ & $182.2 \pm 0.3$ & $288.7 \pm 0.1$ & $32.6 \pm 0.1$ \\
A3 & $363.9 \pm 0.3$ & $250.9 \pm 0.4$ & $409.3 \pm 0.7$ & $153.2 \pm 0.1$ & $231.3 \pm 0.6$ & $28.2 \pm 0.0$ \\
B1 & $346.9 \pm 0.2$ & $267.7 \pm 0.5$ & $522.2 \pm 0.5$ & $208.8 \pm 0.1$ & $210.0 \pm 0.2$ & $7.3 \pm 0.1$ \\
B2 & $348.0 \pm 0.5$ & $289.9 \pm 0.2$ & $587.2 \pm 0.4$ & $214.5 \pm 0.2$ & $259.6 \pm 0.1$ & $8.3 \pm 0.0$ \\
B3 & $348.9 \pm 0.6$ & $300.1 \pm 0.1$ & $658.9 \pm 0.8$ & $211.4 \pm 0.1$ & $244.2 \pm 0.3$ & $14.2 \pm 0.1$ \\
\hline
\end{tabular}


Table 5. Kinetic parameters obtained from the Transference Function model applied to the different Biochemical Methane Potential (BMP) assays. Where $B_{\max }$ : the ultimate methane production, $R_{\max }$ : the maximum methane production rate $\gamma$ : the lag time, $\mathrm{R}$ : regression coefficient, $\mathrm{R}^{2}$ : determination coefficient and $\sigma_{\text {est }}$ : standard error of estimate. OMSW: untreated olive mill solid waste, A1, A2 and A3: pre-treated OMSW under conditions A1, A2 and A3 (121 ${ }^{\circ} \mathrm{C}$ and 1.1 bar for 30, 20 and 15 min, respectively) and B1, B2 and B3: pre-treated OMSW under conditions B1, B2 and B3 (133 ${ }^{\circ} \mathrm{C}$ and 2.1 bar for 30,20 and 15 min, respectively).

\begin{tabular}{cccccccc}
\hline Substrate & $B_{\max }$ & Error $(\%)$ & $R_{\max }$ & $\gamma(\mathrm{d})$ & $\mathrm{R}$ & $\mathrm{R}^{2}$ & $\sigma_{\text {est }}{ }^{*}$ \\
& $\left(\mathrm{~mL} \mathrm{CH}_{4} / \mathrm{g}\right.$ & & $\mathrm{mLCH}_{4} /(\mathrm{g}$ & & & & \\
& $\mathrm{VS})$ & & $\mathrm{VS} \cdot \mathrm{d})$ & & & \\
& & & & & & \\
\hline OMSW & $358 \pm 7$ & 5.0 & $70 \pm 5$ & 0 & 0.969 & 0.941 & 25.6 \\
$\mathrm{~A} 1$ & $380 \pm 5$ & 0.8 & $69 \pm 3$ & 0 & 0.986 & 0.973 & 18.0 \\
$\mathrm{~A} 2$ & $350 \pm 6$ & 0.6 & $73 \pm 5$ & 0 & 0.979 & 0.956 & 20.9 \\
$\mathrm{~A} 3$ & $306 \pm 3$ & 2.9 & $102 \pm 5$ & 0 & 0.989 & 0.979 & 12.0 \\
$\mathrm{~B} 1$ & $296 \pm 3$ & 3.8 & $84 \pm 4$ & 0 & 0.988 & 0.977 & 12.5 \\
B2 & $283 \pm 3$ & 2.4 & $73 \pm 3$ & 0 & 0.991 & 0.983 & 10.6 \\
B3 & $270 \pm 4$ & 1.4 & $58 \pm 4$ & 0 & 0.983 & 0.967 & 15.0
\end{tabular}

